\title{
Carotenogenic enzymes from phycomyces
}

\author{
Peter M. Bramley \\ Department of Biochemistry, Royal Holloway College, Egham Hill, Egham, \\ Surrey, TW20 OEX, England
}

\begin{abstract}
Cell extracts from car mutants of Phycomyces blakesleeanus, which can convert ${ }^{14} \mathrm{C}$-labelled mevalonic acid into unsaturated carotenes, were treated with high ionic strength buffer and a range of detergents in an attempt to solubilise the carotenogenic enzymes. Phytoene synthetase was dislodged from the membrane with high molarity Tris-HCl buffer, but the enzymes which convert phytoene into $\beta$-carotene required detergent treatment for solubilisation. Of the 18 detergents used, only Tweens 40 and 60 and Zwittergent 3-08 solubilised these proteins whilst retaining their enzymic activities.
\end{abstract}

\section{INTRODUCTION}

Since the late 1960s a range of car strains of Phycomyces have been isolated which have deletions in genes involved in carotene biosynthesis (Ref.1 \& 2). Cell-free systems from these mutants have been used to investigate discrete steps in the carotene pathway (Ref.3-6).

Subcellular fractionation of crude cell extracts has shown that a membrane fraction is required for the formation of $\beta$-carotene prior to its deposition in lipid globules (Ref.7 \& 8). Since most protein purification techniques are not applicable to membrane-bound enzymes, it is necessary to solubilise such proteins, whilst retaining their enzymic activities, before purification steps can be attempted. This report presents the results of attempts to solubilise carotenogenic enzymes from the C5 (phytoene-accumulating) and C115 ( $\beta$-caroteneaccumulating) strains of phycomyces. The routine preparation of cell extracts and the purification and radioassay of ${ }^{14} \mathrm{C}-1 \mathrm{abell}$ ed carotenes have been described in detail in earlier publications (Ref.3 \& 5).

TREATMENT WITH HIGH IONIC STRENGTH BUFFER

Cell extracts of $\mathrm{C} 5$ and $\mathrm{C} 115$ were prepared in Tris-HCl buffer, $\mathrm{pH} 8.0$, containing $5 \mathrm{mM}$ dithiothreitol, of molarity 25 to $400 \mathrm{mM}$. Enzymic activities of the resultant cytosolic fractions showed that increasing ionic strength resulted in a parallel rise in phytoene formation from $\left[2-{ }^{14} \mathrm{C}\right]$ mevalonic acid. However, the enzymes catalysing the phytoene to $\beta$-carotene steps were not solubilised under these conditions (Table 1 ).

TABLE 1. The effect of buffer concentration on carotenogenic activities of cytosolic fractions from $\mathrm{C} 5$ and $\mathrm{C} 115$

\begin{tabular}{cccc}
\hline $\begin{array}{l}\text { Buffer } \\
\text { concentration }(\mathrm{mM})\end{array}$ & $\begin{array}{c}\text { C5 } \\
\text { Phytoene }\end{array}$ & Phytoene & $\begin{array}{c}\text { Control } \text { activity }^{\text {C115 }} \\
\text { B-Carotene }\end{array}$ \\
\hline 400 & 96.7 & 95.1 & 3.1 \\
200 & 47.3 & 31.6 & 1.9 \\
100 & 41.5 & 15.7 & N.A. \\
25 & 7.5 & 10.5 & N.A. \\
\hline
\end{tabular}

N.A., not assayed; a, control activity refers to the incorporation of [2-14 C]mevalonic acid $(1 \mu \mathrm{Ci})$ into carotenes with crude cell extracts (10000 x g supernatant) 


\section{TREATMENT WITH DETERGENTS}

Cell extracts of the C115 strain were treated with 18 different detergents, each over a 0.3 $3.08(\mathrm{w} / \mathrm{v})$ concentration range. After leaving these extracts over ice for $30 \mathrm{~min}$, the incorporation of $\left[2-{ }^{14} \mathrm{C}\right]$ mevalonic acid into phytoene and $\beta$-carotene was assayed. The detergents varied considerably in their effects on carotenogenic activities. Of the 9 ionic surfactants tested, only Zwittergent 3-08 and 3-10-treated extracts retained any activities, even at a 0.38 concentration. The non-ionic detergents were generally less inhibitory, with up to $47 \%$ of control activities being retained with Tweens 40,60 and 80 at 18 concentrations. It was also found that these 3 detergents caused a stimulation of phytoene formation from mevalonic acid e.g. 1.5 fold with Tween 40 . The Zwittergent 3-08-treated preparation was stimulated 3.5 fold with respect to phytoene biosynthesis.

\section{SOLUBILISATION OF CAROTENOGENIC ACTIVITIES WITH DETERGENTS}

Attempts to solubilise carotenogenic enzymes from the C115 strain were carried out with Tweens 40 and 60 and Zwittergent 3-08, since these 3 surfactants had shown minimal inhibition of $\beta$-carotene formation in vitro. Both Tween 60 and Zwittergent 3-08 (at $18 \mathrm{w} / \mathrm{v}$ ) solubilised almost $50 \%$ of these enzymes, as judged by the activities of cytosolic fractions (Table 2).

TABLE 2. Solubilisation of carotenogenic activities of C115

\begin{tabular}{|c|c|c|c|c|c|c|}
\hline \multirow{2}{*}{ Detergent $(1 \% \mathrm{w} / \mathrm{v})$} & \multicolumn{3}{|c|}{ Incorporation (dpm) of } & \multicolumn{3}{|c|}{ [2-14 $\mathrm{C}]$ mevalonic acid $(1 \mu \mathrm{Ci})$} \\
\hline & $s_{10}$ & $S_{105}$ & ${ }^{8 S_{10}}$ & $s_{10}$ & $S_{105}$ & ${ }^{8} S_{10}$ \\
\hline Control & 16283 & 5145 & 31.6 & 56578 & 1075 & 1.9 \\
\hline Tween 60 & 46069 & 41601 & 90.3 & 76226 & 35418 & 46.5 \\
\hline Tween 40 & 43527 & 63195 & 145.2 & 44000 & 9445 & 21.2 \\
\hline Twittergent $3-08$ & 26503 & 93501 & 352.8 & 59978 & 29671 & 49.5 \\
\hline
\end{tabular}

$\mathrm{S}_{10}, 10000 \mathrm{x}$ g supernatant (crude cell extract); $\mathrm{S}_{105^{\prime}} 105000 \times \mathrm{xg}$ supernatant (cytosolic fraction)

\section{STABILITY OF DETERGENT-SOLUBILISED PREPARATIONS}

On storage at $-70^{\circ} \mathrm{C}$, the Tween 40 and 60 preparations were considerably more stable than the Zwittergent 3-08-treated extract (Table 3 ).

TABLE 3. The effect of storage on $\beta$-carotenogenic activities of detergentsolubilised extracts of C115

\begin{tabular}{cccc}
\hline $\begin{array}{c}\text { Storage period } \\
\text { (weeks) }\end{array}$ & $\begin{array}{c}1 \% \text { Tween } 60 \\
\text { solubilised }\end{array}$ & $\begin{array}{c}\text { \& Activity remaining } \\
1 \% \text { Tween } 40 \\
\text { solubilised }\end{array}$ & $\begin{array}{c}\text { 18 Zwittergent 3-08 } \\
\text { solubilised }\end{array}$ \\
\hline 0 & 100 & 100 & 100 \\
2 & 89 & 78 & 1.4 \\
4 & 31 & 40 & 0.73 \\
\hline
\end{tabular}

\section{CONCLUSIONS}

The inhibitory effects of detergents on carotenogenic activities of phycomyces cell extracts demonstrates the sensitivity of these enzymes to surfactants. Since all of these compounds have been used successfully in other membrane protein solubilisation studies (see Ref.9), the results presented in this report emphasise the necessity for an empirical approach to new investigations of this type.

The 3 detergents which solubilised the carotenogenic enzymes whilst retaining biological activity (Table 2) are either non-ionic (the Tweens) or have physical properties similar to non-ionic surfactants (Zwittergent $3-08$ ). This also suggests that the enzymes catalysing 
the conversion of phytoene to $\beta$-carotene are peripheral membrane proteins, as such detergents cannot dissolve the lamellar structure (Ref.10). However, since these enzymes are not released by high ionic strength buffer, in contrast to phytoene synthetase (Table 1), it is likely that the latter enzyme is loosely associated with the membrane by electrostatic forces.

Since Tween 60-solubilised preparation is both stable on storage (Table 3), and contains good yields of all the carotenogenic enzymes, it is likely to be the most useful for further studies on the purification of these enzymes.

out these studies.

$\underline{\text { Acknowledgement }}$ - I would like to thank Dr. Richard F. Taylor for his advice through

\section{REFERENCES}

1. E. Cerdá-Olmedo and S. Torres-Martínez, Pure \& Appl.Chem. 51, 631-637 (1979).

2. E. Cerdá-Olmedo, Methods Enzymol. in the press (1984).

3. P.M. Bramley and B.H. Davies, Phytochemistry 14, 463-469 (1975).

4. P.M. Bramley, A. Than and B.H. Davies, Phytochemistry 16, 235-238 (1977).

5. G. Sandmann, P.M. Bramley and P. Böger, Pestic.Biochem.Physiol. 14, 185-191 (1980).

6. A. de la Concha, F.J. Murillo, E.J. Skone and P.M. Bramley, Phytochemistry 22, 441-445 (1983).

7. G.J.P. Riley and P.M. Bramley, Biochim.Biophys.Acta 450, 429-440 (1976).

8. G.J.P. Riley and P.M. Bramley, Cytobios 34, 97-104 (1982).

9. A.H. Maddy and M.J. Dunn, Biochemical Analysis of Membrane Proteins (A.H. Maddy, ed.), p.177, Chapman and Hall, London (1976).

10.A. Helenius and K. Simons, Biochim.Biophys.Acta 415, 29-79 (1975). 